\title{
THE ROLE OF PHRASEOLOGY IN THE RUSSIAN POPULAR WRITER'S WORKS
}

\author{
Imre Pacsai \\ Habilitated Doctor of Philological Sciences, Professor \\ Nyíregyháza High School \\ (Nyíregyháza, Hungary) \\ e-mail: drpacsai@gmail.com
}

\begin{abstract}
The importance of the research of phraseology is mentioned in the philological works of the 20th century, which reflects the influence of the spiritual heritage of W. von Humboldt.

During the research of Russian spoken language we observed the intensive application of idioms of phraseology in the folklore and in the popular writers works. The Russian phraseology is based on the idioms of Russian popular language. The origin of the idioms are used in the descripiton of the atmosphere of the Russian country, explaining its role in the works of Russian country-prose and in the works of other popular writers.

The realistic representation of the „couleur local” of the Russian country was determined by the typical category of the Russian folk language.
\end{abstract}

Keywords: the research of phraseology, Russian phraseology, idioms of spoken language, the atmosphere of the Russian country, country-prose, realistic representation, typical categories.

\section{РОЛЬ ФРАЗЕОЛОГИЧЕСКИХ ЕДИНИЦ В ПРОИЗВЕДЕНИЯХ РУССКИХ НАРОДНЫХ ПИСАТЕЛЕЙ}

\author{
Имре Пачаи \\ Хабилитированный доктор филологических наук, профессор \\ Ньиредьхазская Высшая школа \\ (Ньиредьхаза, Венгрия) \\ e-mail: drpacsai@gmail.com
}

\begin{abstract}
Аннотация. Исследование фразеологии является важной задачей лингвистики, так как освещает взаимосвязи между языком и культурой, на что ориентировал В. фон Гумбольдт.

В настоящей статье рассмотрены русские народные изречения, использованные в работах русских писателей, которые отражают жизнь села и сознательно используют стилистические элементы русской народной речи. Данные вопросы непосредственно связаны с основными категориями русской народной речи и воспринимаются как признаки этого специфического стиля. Язык русского фольклора - сокровища русской народной культуры - неотделим от данного стиля, что подтверждается выводами В. Даля и А. А. Потебни.
\end{abstract}

Ключевые слова: фразеологические единицы, этикетные формулы, русская народная речь, язык фольклора, русские народные писатели, стилистические признаки 


\section{ВВЕДЕНИЕ}

В настоящей статье рассматривается роль фразеологических единиц в создании языковой модели мира и отображении национального менталитета в произведениях русских писателей, пишущих на сельскую тему. В работах, оценивающих специфику русской деревенской прозы 60-70-х годов XX века, отражается достоверное изображение жизни русской деревни и речи простых людей. В этих работах также упоминается о языковых средствах, содействующих верному изображению couleur local русской деревни.

Работы, вышедшие в 90-ые годы XX века, свидетельствуют об актуализации данных вопросов, так как в упомянутых работах уделяется внимание взаимовсязи языка и культуры, что восходит к наследию В. ф. Гумбольдта. В книге «Жизнь происходит от слова» (1999) В. В. Колесов дает следующую дефиницию национальной ментальности: «Ментальность есть средство национального самосознания и способ создания традиционной картины мира, коренящиеся в категориях и формах родного языка.» (Kolosov 1999: 148)

Наш интерес к вопросам русской народной речи возник при изучении специфических структур русского языка, названные термином «парные слова» в работах русских исследователей. Ориентиром и опорой нашего исследования служила работа „Из записок по русской грамматике. Т. 3.” (1899) А. А. Потебни, в которой тщательно изучены семантические и стилистические вопросы, связанные с упомянутыми языковыми единицами.

А. А. Потебня наметил путь нашего исследования, указывая на то, что парные слова используются в первую очередь в русском фольклоре и в просторечии, в языке неграмотных людей. При изучении этих вопросов мы наталкивались на интересные проблемы. Изученные нами парные слова в русском языке не рассматривались чуть ли не сто лет, несмотря на то, что А.А. Потебня посвятил целые разделы этим специфическим структурам в своей книге. Ни один пример не представлен ни в работе Словосложение в русском языке Василевской, ни в работе Русская разговорная речь Е.А. Земской (1973). Отношение к наследию А. А. Потебни освещеется Р. А. Будаговым, представляющего деятельность великого ученого. Направление структурализма долгое время затмило славу и достижения А. А. Потебни в русской лингвистике.

При изучении специфических признаков русской народной речи для нас служила работа Практическая стилистика (1974) Д. Э. Розенталя, в которой тщательно изучены основные категории русской народной речи. В этой работе представлены ее типичные структуры, которые игнорировали другие исследователи.

В русской лингвистике сам термин «русская народная речь» использован впервые в работе Русские фразеологизмы В. П. Фелицыной и В. М. Мокиенко (1990), в которой рассмотрены, в частности, и парные слова в составе изученных фразеологизмов. При трактовке оборота подобрупоздорову установлено следующее: „Выражение построено по типичной для народной русской речи формуле" (В. П. Фелицына и В. М. Мокиенко1990: 105)

Про категории упомянутой русской народной речи мы могли почерпнуть информацию из работы Д. Э Розенталя, так как в работе Е. А. Земской подчёркивается то, что информаторами ее работы Русская разговорная речь могли быть только городские жители, родившиеся в городе и закончившие среднюю школу. Таким образом, известные народные сказители и певцы, которые, по мнению Т. Г. Ивановой (1989), являются хранителями сокровища русской культуры, жившие и живущие в маленьких деревнях, вдали от города, не могли бы служить информаторами данной стилистической работы. 
Данной концепции противоречит мнение В. Даля, излагаемое в разделе Напутное в сборнике русских пословиц: „Что за пословицами и поговорками надо идти в народ в этом никто спорить не станет, в образованном и просвещенном обществе пословицы нет...

Готовых пословиц высшее общество не принимает, потому что это картины чуждого ему быта, да и не его язык.” (Даль 1989: 7)

Выводы Ф. П. Филина соответствуют мнению В. Даля о роли русской народной речи в формировании национального языка: „Если бы мы отождествили литературный язык с национальным языком, то должны были бы исключить из состава нации всех, кто не владел или не владеет литературным языком. ...Да и в наше время еще миллионы русских пока не в достаточной степени владеют литературным языком и говорят на полудиалектах, а некоторая часть населения сохраняет архаичные говоры.” (Филин 1977: 8)

Многие из писателей-деревенщиков, использующих стилистические элементы народной речи, были сверстниками Ф. П. Филина. Использование народной русской речи в их произведениях соответствует выводам Ф. П. Филина и способствует созданию полнокровного изображения деревенского быта.

Перелом старой концепции, упомянутой Р. А. Будаговым, и новый подход характеризуют деятельность Д. Э. Розенталя и В. М. Мокиенко. При чтении работы Загадки русской фразеологии (2007) В. М. Мокиенко мы узнали, что рецензентом его книги был Д. Э. Розенталь, что отражает новую концепцию известного русского фразеолога.

При изучении стилистических признаков русской народной речи богатым источником нам служили произведения о деревенской жизни русских писателей П. И. Мельникова, П. Бажова, М. Шолохова В. Шукшина, В. Белова, С. Залыгина, В. Распутина, в которых звучит речь русского народа. В этих работах важными стилистическими средствами являются и народные изречения, отражающие мысли и чувства простых людей. В этих произведениях мы наблюдали специфическую лексику, морфологические структуры, фразеологические обороты, этикетные формулы, пословицы, типичные элементы данного стиля: „- А бабы набежали первые-то. ” (Баж. 28); „Не может, дескать, так быть.” (Баж. 18); „- Поезжай куда хошь, любо-дорого!” (Бел. 457); „Соображсают стоят. Раз говорят, значит, был.” (ШБ 169); „Иди промочи горло-то, заговорили сзади.” (ШБ 152); „После бани четвертку жадничал выпить, а она взяла шубку купила.” (ШР 303); „Думай не думай сто рублей не деньги.” (ШР 28); „Однажды раным-рано Иван Африканович зашел в огород” (Бел. 85) „—Доброго здоровьица!” (Бел. 235); „- Хватит тебе халтуру сиибать, иди в лес.” (Бел. 353); „—Ой, к лешому, к водяному! ” (Бел. 44); „- Еще утрось в Соленой Пади известно было. ” (3С 275); „И сама же бежит-ревет” (ЗК 379); „- А меня ты знать не знаешь и видеть не видел. ” (ЗК 148); „Сильно уже хворая была Елиза вета” (ЗС 140); „Тайга на десятки верст гудом гудела от машин” (Расп. 40); „А там досматривай не досматривай... у всех вода” (Расп. 37); „Колчаковцы, захватив остров, слыхом не слыхали про Пашу” (Расп. 129) „Взял сколупнул бородавку и весь кровью изошел" (Расп. 16).

В книге Д. Э. Розенталя «Практическая стилистика русского языка» (1974) установлены категории русской разговорной речи, уделяется внимание и фразеологическим единицам, которые, по его мнению, являются важными элементами народной речи. Он подчеркивает тот факт, что значительную часть русского фразеологического фонда составляет разговорная фразеология. Фразеологические единицы данного стиля, подобно разговорной лексике, стилистически весьма выразительны. Их характеризуют разнообразные экспрессивно-оценочные оттенки. 
Вопросы, касающиеся проблематики национального менталитета, проявляются и в области фразеологии, что подтверждается выводами В. Н. Телии (1996), рассматривающей данный круг вопросов. В книге «Русская фразеология» В. Н. Телия определяет связь между фразеологией и национальным менталитетом: «Фразеологический состав языка - это зеркало, в котором лингвокультурная общность идентифицирует свое национальное самосознание.» (Телия 1996: 9)

В книгах В. М. Мокиенко «В глубь поговорки», «Образы русской речи», «Загадки русской фразеологии» рассматриваются важнейшие вопросы фразеологии с учетом взаимоотношения языка и культуры. Исследователь подчеркивает, что изучениие соотношения языка и культуры является актуальной проблемой гуманитарных наук, в том числе и фразеологии.

При изучении стилистических категорий русской народной речи, использованных в произведениях «народных» писателей обнаруживается интенсивное использование фразеологических единиц, которые отражают менталитет изображенного культурного и языкового сообщества.

О роли народных изречений в национальной культуре говорит В. И. Даль в предисловии «Напутное», написанном к своему сборнику русских народных пословиц и поговорок. Он подчеркивает, что в народных изречениях отражается мудрость народа, накопленный опыт о мире и сущность своего мировоззрения. По мнению В. И. Даля, народные изречения отражают характерные черты русского народного языка.

Положение В. И. Даля о роли народных изречений в русской народной культуре подтверждает значение более углубленного анализа рассматриваемых нами вопросов.

В романе П. И. Мельникова «На горах», в котором изображена жизнь Поволжья, используются элементы русской народной речи. Это объясняется стремлением писателя-этнографа достоверно изображать обычаи и традиции русского народа, что отражает его авторскую концепцию. Об этом свидетельствуют жанровые картины праздника крестины, где звучат старые приговорки, отражающие древние народные традиции. Хозяйка Аграфена Петровна обращается к гостям следующими словами: «- Садитесь, гости дорогие, за скатерти браные, за напитки пьяные, за хлеб, за соль, за крестильную кашу да за курничок, - приговаривала Аграфена Петровна усаживая гостей за обеденный стол. » (МЕЛ II/198)

О значении приговорки, использованной при угощении гостей, свидетельствует мнение писателя: «За столом хозяйничала богоданная дочка Потапа Максимыча Аграфена Петровна. И всето старозаветными приговорками она приговаривала, без коих наши прадеды куска хлеба, бывало, не съедят в гостях, пока не услышат их из ласковых уст хлебосольной хозяйки». (МЕЛ II/198)

Положение писателя о роли старозаветных приговорок в жизни русского народа отражает его авторскую концепцию. Достоверное изображение народной традиции требует и представления речевых элементов ритуала. Аутентичность поговорки, использованной в речи хозяйки, подтверждается работой «Русские пословииы и поговорки» В. И. Даля, в которой зафиксирована эта ФЕ: «Садитесь за скатерти браные, за напитки пьяные.» (Д ІІ / 236)

При описании угощения гостей используются и другие приговорки, что свидетельствует об их роли в выполнении древних ритуалов. Писатель считает необходимым представление и этих изречений с целью достоверного изображения праздничного обеда. В речи хозяина тоже обнаруживаются аутентичные приговорки: «- Уговор дороже денег, - подхватил Потап Максимыч, когда уселись все. - Слушайте хозяина, гости дорогие, - на собак покидайте одни кости, остальное сами доедайте, чтоб на столе у меня все было чистехонько. Теперича воля не 
ваша, а моя да хозяюшкина. Сами знаете, что по старому святому завету гость хозяину не указчик — что поставят перед ним, то и кушай да хозяев во всем слушай. » (МЕЛ II/198);

Обороты, использованные хозяином, также являются элементами народного речевого этикета, что подтверждается данными этнографических работ: «Уговор дороже денег» (РПП 310); «гость хозяину не указчик» (Д ІІ / 235); (РПП 68); «что поставят перед ним, то и кушай да хозяев во всем слушай» (РПП 329).

Эти примеры из романа отражают сущность изученных вопросов, взаимосвязи между культурой и языком. Об обязательном характере приговорок при угощении гостей указывает на то, что поведение членов данного культурного и языкового сообщества определяется и традиционными изречениями, так как они отражают и отношение хозяина к гостям. Каждому члену данного сообщества известно значение упомянутых народных изречений.

Использование в романе этикетных формул содействует созданию языковой среды и настроения изображенной действительности. Описание народного ритуала «бабина каша», связанного с крещением новорожденного, является типичным мотивом романа, где совместно с этнографическими элементами изображены народные изречения и специфические категории русской народной речи. Обрядом управляет бабка-повитуха, которая следит за выполнением старых отеческих уставов.

Бабушка повитуха Дарья Никитишна с низким поклоном поставила кашу перед Васильем Борисычем и такие речи примолвила ему по-старинному, по-уставному:

«- Что туман на поле, так сынку твоему, покрещенному счастье-талан на весь век его! ...Кушай за здоровье сынка, свет родитель-батюшка, — жить бы сынку твоему на белом свете подольше, смолоду отиа с матерью радовать, на покой жизни кормить-поить, а помрете когда поминки творить!» (МЕЛ II/205);

Важная часть приговорки повитухи соответствует ФЕ, зафиксированной в сборнике русских народных пословиц и поговорок В. Даля: «Как в поле туман, так ему счастье-талан (слова повитухи за кашей)» (Д $\mathrm{I} / 296)$.

Хранителем и исполнителем народных обрядов является повитуха, что подтверждается и ее словами: «-Изволь, государь-батюшка, скушать все капельки, не моги, свет-родитель, оставлять в горшке ни малого зернышка. ... Не хочешь докушать, моего приказа послушать - рукам волю дам. Старый отецкий устав не смей нарушать - исстари так дедами-прадедами уложено и навеки ими установлено.» (МЕЛ II/205).

В речи бабы-повитухи совместно с типичной формулой ритуала используются и другие элементы русской народной речи. Сочинительные сложения кормить-поить, дедами-прадедами которые называются и термином парные слова тоже являются элементами народной речи в романе писателя-этнографа. Заслуживает пристального внимания, что структура счастье-талан является ключевым элементом формулы, выражающей благопожелания повитухи. О типичном характере парных слов в русской народной речи говорится в работах Д. Вайса $(2003,2011)$, изучающего спаренные глаголы в русском языке. Выводы швейцарского исследователя подтверждаются достижениями А. А. Потебни (1899), рассматривающего данный специфический вид деривации русского языка, использованный в фольклоре. О фразеологическом характере этих структур свидетельствует историко-этимологический словарь Русская фразеология (2005), в котором рассматриваются многие примеры парных слов. 
В произведениях, использующих категории разговорной речи часто используется этикетная формула поздравления Здорово!, которая типична для русской народной речи. В романе П. И. Мельникова наблюдаются следующие примеры: « - Здорово, Ермило Матвеич! - крикнул Самоквасов, поравнявшись с Сурминым.» (МЕЛ 347); «- Здорово, дружище, - протягивая ему руку, молвил Марко Данилыч.» (МЕЛ II/149); «- Здорово, Пантелеюшка, — ласково молвил Патап Максимыц.» (МЕЛ II/428)

Народная этикетная формула поздравления также используется в произведениях В. Шукшина с целью создания «couleur local» деревни: «- здорово, сосед, - первым поприветствовал Егор.» (Ш 210); «-Здорово, — ответил Яша.” (Ш 210); «Степан ульгбнулся ей: — Здорово, Нюра.» (ШР 40);

Эта формула типична и для речи героев В. Белова: «- здорово, Степановна! - Иван Африканович бодрился...» (Бел 16); «- Здорово, бабы!!» (Бел 19); «-Здорово, Ивановна!» (Бел 46) «-3дорово, Федулиха! Суn-то есть?» (Бел 288); «-Здорово, сват!» (Бел 450).

Крестьянские герои С. Залыгына тоже часто поздравляют друг друга этой формулой: «Здоров, Гришуха!; - Здорово, Никола!» (ЗК 121); „- Здорово, Брусенков! - протянул ему руку Ефрем.» (ЗС 29). В повести «Прощание с Матёрой» В. Распутина тоже используется эта формула: «-Здорово, Дарьюшка!» (РАC 24).

О типичном использовании этикетной формулы Здорово! в русской народной речи свидетельствуют и народные сказки, зафиксированные в сборнике А. Н. Афансьева: «- Здорово, хозяин! / - Здорово, служба!» (НРС 300); — Здорово, сват! — Здорово! » (НРС 303)

Заслуживает внимания, что герои русского фильма «Капитанша», сюжет которого изображает быт русских моряков в наши дни, часто звучит формула Здорово! при встрече действующих лиц.

В повестях В. Шукшина крестьянские герои прощаются друг с другом используя формулу Будь здоров!: «- Вот так...Будьте здоровы пока. — Спирька вышел.» (ШБ 74); «- Ну, бывай здоров! — Федя поднялся уходить.» (Ш 139); «—Будь здоров. Забегай когда....” (Ш 140); «—Будь здоров! Сам заходи.” (Ш 210).

В романе «Соленая Падь» С. Залыгина тоже часто используется оборот Будь здоров!: «- $C$ богом, Ефрем...Будь здоров!» (ЗС 102); «-Ну! Бывайте здоровы, братья-товарищи! Встретимся ишио.» (ЗС 102); «- Ну, тогда, прощай, Власихин! — сказал Перевалов - Бывай здоров!» (3С 29); «— Будь здороая, Дора! — наклонился, почеловал в лоб и ушел» (ЗС 437).

В литературных произведениях используются и другие аутентичные обороты поздравления, служащие созданию языковой среды деревни, зафиксированные в фразеологическом словаре, «Сколько лет, сколько зим! Как поживаете?» (МЕЛ II/153); «прощай, мол, батюшка, лихом не поминай.» (МЕЛ 445) / (РФ 388); « - Добро пожаловать, - весело - сказал он.» (МЕЛ 69); «Доброго здоровья, — приветствовал старик в иляпе.» (Ш 33); « - С легким паром...» (ШР 151)

В народной фразеологии ФЕ жив-здоров тоже употребляется в роли этикетной формулы, о чем свидетельствуют диалоги героев в романе П. И. Мельникова: «- Нет ли каких новостей? Все ли жеивы-здоровы? - Все слава богу жнивы-здоровы, отвечает Ермило Матвеич.» (МЕЛ 399).

О частоте использования ФЕ жив-здоров свидетельствует роман М. Шолохова «Тихий Дон». Донские казаки интересуются здоровьем своих знакомых, употребляя данный оборот: «Наталья $c$ внуками как? Живь-здоровы?» (Шол. II/ 65); «Здравствуй, сват! Живой-здоровый?» (Шол. II/ 96); «Супруга ваша жнивая-здоровая?» (Шол. III/ 60); «Натальюшка жсива-здорова?»” (Шол. III/ 140); 
«Живой-здоровый он?» (Шол. IV/ 249); «Старик-то мой ж⿻ивй-здоровый?» (Шол. IV/ 249); «Детушки жсивы-здоровы?» (Шол. IV/ 422);

Эта фразеологическая единица используется и у П. Бажова, В. Шукшина и С. Залыгина: «Микола жив-здоров, скоро домой придет» (Б 83); «—Слава богу, живь--здоровы.»” (ШБ 446); «все они были живы и здоровы» (ЗК 293)

Фразеологическая единица жсив-здоров рассматриваетсся и в работе «Русская фразеология» (2005), в которой указано на то, что она возникла под влиянием контактов с соседними народами, живущими в Волжском бассейне (РФ 221).

Структура хлеб-соль, трактуемая в работе А. А. Потебни (1899), тоже типичный элемент русской фразеологии. В. Шукшиным используется данная ФЕ в роли этикетной формулы: «-Хлеб да соль! - сказал Иван, подходя к тем, которые выпивали.» (ШБ 418). В романе П. И. Мельникова наблюдается применение этой структуры: «—мы больше тридцати годов хлеб-соль наживали....» (МЕЛ 110); «— Друзьями мыс с ним не бывали, а знакомство и хлеб-соль водили.» (МЕЛ II/211); «Хлеб-соль меж собой водили.... » (МЕЛ II/212)

Фразеологическая единица Чай да сахар! также относится к народным формулам, связанным с угощением. «—Чай да сахар! —молвил Лука Данильчџ (МЕЛ 254)

Экспрессивность ФЕ дает возможность для выразительного изображения характера действующих лиц. В повести «Обида» В. Шукшина фразеологическая единица вынь да положь, использованной надменной продавщицей явно выражает ее высокомерие и враждебное отношение к простолюдину Сашке: «Да вот директора - стоит требует!... Вынь да положь директора! Фонбарон. Пьянчуги.» (ШБ 170).

П. И. Мельников выражает свое отношение к хитрой и алчной молодой жене богатого купца, которая сумела заполонить старого мужа: «чего бы ни захотела «свет душа Паранюшка» у него, тотчас вынь да положь» (МЕЛ 160). П. И. Мельников с большим мастерством использует фразеологическую единицу вынь да положь!, которая, по толкованию С. И. Ожегова, обозначает исполнение капризного требования (ОЖ 101).

В романе «Комиссия» С. Залыгина при помощи этого оборота выражается возмущение кержаков из-за отказа Лизаветы, которая не хотела выйти замуж за одноглазого парня: «- $A x$, вот как! Когда семеро ваших желают за наших, так вам, полувятичам, вынь да положь, а когда наш один пожелал взять вашу - так она и глядеть на его не желает?! » (ЗК 77)

Отрицательное отношение Анисьи к богатой и гордой женщине низкого происхождения выражает используемая ей ироническая пословица: «-A еще барыня, благородная! Родсловная видишь!... А какое у них родословье? От ёрника балда, от балды шишка, от иишки ком! А вы еще, сударыня, такую паскуду до себя допускаете!» (МЕЛ 36).

Пословица, отражающая народный юмор зафиксирована в сборнике В. И. Даля «От ёрника балда, от балды шишка, от шиики ком, а черт ли в нем?» (Д/ ІІ/ 186). Использование этой поговорки доказывает глубокое знание народных изречений П. И. Мельниковым.

В представленных нами произведениях используются самые типичные элементы русской фразеологии, что отражает стремление писателей к достоверному изобрадению речи народных героев. В рассказе «Сельские жители» Шукшина использована ФЕ Свят, свят! (Шр 27), которая изучена в работе В. М. Мокенко «Образы русской речи». Об этой ФЕ установлено, что она восходит к древним русским верованиям. О глубоком знании русской народной речи свидетельствует тот факт, 
что писатели используют элементы русской народной фразеологии. Об аутентичности народных изречений, использованных в трактуемых нами произведениях свидетельствуют этимологические данные словаря «Русская фразеология»:

Мельников: куда глаза глядят (МЕЛ 9) / (РФ 139); белу свету (МЕЛ 10) / (РФ 626); встречному и поперечному (МЕЛ 593) (РФ 128); друг и приятель закадычный (МЕЛ 230)/(РФ 202); в бараний рог согну" (МЕЛ 409) / (РФ 597); дело в шляпе" (МЕЛ 238) /(РФ 179); держите карман шире!” (МЕЛ 409) / (РФ 290); сору из избы не выносят" (МЕЛ 506) / (РФ 659);

Бажов: с бору да с сосенки, (Баж. 161) / (РФ 62); с грехом пополам (Баж. 181) / (РФ 164); сбоку припёка (Баж. 202) / (РФ 573); кукишку покажут (Баж. 215) / (РФ 363); ухом не ведет (Баж. 268) / (РФ 716); ни слуху ни духу (Баж. 260) / (РФ 646); по зеленой улице (Баж. 328) / (РФ 709);

Шукшин: подешевле и посердитей (ШР 27) / (РФ191); как нерезаных собак (ШР 46)/ (РФ 649); сиротой казанской (ШР 64) / (РФ 636); гол как сокол (ШР 73) / (РФ 654); шишка на ровном месте (ШР 55) /(РФ 769; с какой стати (ШР 119) / (РФ 665); остались с носом." (ШР 130) / (РФ 479); не меряй всех на свой аршин." (ШБ 117) /(РФ 33); через пень колоду. (ШР 148) / (РФ 516); воробей подстреленный. (ШР 304) / (РФ 119); как с гуся вода: (ШР 96) / (РФ 172);

Белов: показал кузькину мать (Бел. 160) / (РФ 422); показывать кукиш (Бел. 212) / (РФ 363); ребра-то посчитаю (Бел. 415); балясы точить (Бел. 373) / (РФ 42); ни слуху ни духу. (Бел. 427); ,любо-дорого (Бел. 457); еле-еле дуиа в теле (Бел. 489); хочется и колется (Бел. 456); наплакал кот (Бел. 447) / (РФ 351); и оставили с носом (Бел. 506) / (РФ 479);

Залыгин: бог на душу положсит (ЗК 9) / (РФ 57); черная кость (ЗК 161) / (РФ 381); двои canoz пара (ЗК 62) / (РФ 623); задним умом (ЗК 271) / (РФ 711); кишка тонкая (ЗС133) / (РФ 302); трын-трава (ЗК 391) / (РФ 701); от горика два вершка (ЗК 357) / (РФ 601);

Распутин: типун ей на язык (Расп. 16) / (РФ 691); останутся на бобах (Расп. 17) / (РФ 57); не тяни кота за хвост (Расп. 23) / (РФ 352); арапа не заправляй (Расп. 24) / (РФ 29); без году неделя (Расп. 24) / (РФ 144); с три короба (Расп. 65) / (РФ 345); семь пядей во лбу (Расп. 77) / (РФ 585); хоть кол на голове теши (Расп. 69) / (РФ 317); к иерту на кулички (Расп. 120) / (РФ 57); спит без задних ног (Расп. 154) / (РФ 5472).

Представленные нами фразеологические единицы являются собственно русскими, поэтому они имеют органическую связь с другими категориями русской народной речи. Эти народные изречения содействуют созданию языковой картины мира и отражению русского национального менталитета.

\section{ЗАКЛЮЧЕНИЕ}

При изучении роли фразеологических единиц в литературных произведениях на сельскую тему выяснилось, что народные изречения служат важными средствами языка писателя, так как эти элементы языка обладают экспрессивностью, и они способны выразить социальный фон произведения. Частота использования данных структур подтверждает их сознательное применение писателем с целью создания языковой среды изображенного мира и для отражения характерных черт своих героев.

При изучении этимологии и стилистического характера фразеологических единиц мы убедились в том, что писатели с большим мастерством выбирают исконно народные структуры для создания языкового и культурного фона. Рассмотренные нами литературные произведения убедительно доказывают, что представленные нами писатели глубоко знают русские народные культурные и языковые традиции. Использованные ими фразеологические единицы органически 
связаны с другими элементами русской народной речи и явно отражают характер русского культурного и языкового общества.

\section{LIST OF REFERENCES}

Budagov, R. A. (1986). A. A. Potebňa kak jazykoved-myslitel' Voprosy jazykoznanija 3/ 3-15

Dal',V. I. 1984. (1984). Naputnoje. Poslovicy russkogo naroda. Sbornik V. Dal'a v dvuch tomach, 5-21. Moskva.

Filin, F. P. (1977/5). Sovetskoje jazykoznanie: teorija i praktika. Voprosy jazykoznanija 3-12.

Felicyna, V. P., Mokienko, V. M. (1990). Russkie frazeologizmy «Russkij jazyk» Moskva.

Ivanova, T. G. (1989). Russkije narodnyje skaziteli. «Pravda» Moskva.

Kolesov, V. V. 1999 Žizñ poishodit ot slova. «Zlatoust» Sankt-Peterburg.

Mokienko,V. M. 1999. V glub’ pogovorki. «MiM» «Paritet», Sankt-Peterburg.

Mokienko,V. M. (1999). Obrazy russkoj reči. FILO-PRESS. Sankt-Peterburg.

Mokienko, V. M. (2007). Zagadki russkoj frazeologii. «Avalon» Sankt-Peterburg.

Mokienko, V.M. (2019) WINGED WORDS IN SCHOOL: MINIMUM AND MAXIMUM. International Scientific-Pedagogical Organization of Philologists “WEST-EAST” (ISPOP). Scientific Journal WESTEAST. Vol 2/1 N1 (October, 2019). pp. 11-16. doi: https://doi.org/10.33739/2587-5434-2019-2-11-16

Potebňa, A. A. (1968). Iz zapisok po russkoj grammatike T. 3. «Prosvesčenie» Moskva.

Rozental', D. E. (1974). Praktičeskaja stilistika russkogo jazyka . Moskva.

Telija, V. N. (1996). Russkaja frazeologia. «Russkij jazyk» Moskva ,

Weiss, D., Weiss (2011). Verb serialization in North East Europe: the case of Russian and its Finno-Ugric neighbours. To app. in: B: Hansen \& B. Wiemer (eds) Language contact and grammatizalization. Amsterdam-Philadelphia 2011. 1-40.

Vorobjov, V. V. (1997). Lingvokulturológija. Teorija i metody. Moskva.

Weiss, D. (2003). Russkie dvojnyje glagoly i ich sootvetstvija v finno-ugorskich jazykach. Russkij jazyk v naučnom oszvesčenii. 2 (6) 37-59. Moskva.

Žukov, V. P. (1978). Semantika frazeologičeskich oborotov Moskva.

\section{Источники}

Баж. : Bažov, P. (1947). Malachitovaja škatuka. Rasskazy, «Sovetskij pisatel’» Moskva.

Бел.: Belov, V. (1984). Povesti i rasskazy. «Hud literatura», Moskva.

Д: Poslovicy russkogo naroda. Sbornik V. Dal'a v dvuch tomach, «Hud. literatura» (1984) Moskva.

ЗК: Zalygin, S. (1976). Komissija «Molodaja gvardija». Moskva.

3C: Zalygin, S. (1976). C. Solonaja Pad”, «Sovremennik». Moskva.

МЕЛ: Mel'nikov, P. I. (Andrej Pečorskij) (1988). Na gorach. «Pravda» Moskva.

HPC: Narodnyje russkije skazki iz sbornika A. N. Afanasjeva «Hud literatura» (1983). Moskva.

ОЖ: Ožegov, S. I. (1987). Slovar' russkogo jazyka. «Russkij jazyk» Moskva.

Расп. : Rasputin, V. (1983). Povesti. «Belarus'» Minsk.

РПП : Russkije poslovicy i pogovorky 1988. «Hud. literatura» Moskva.

РФ: Birich, A., Mokienko, V. M., Stepanova, L. I. 2005. Russkaja frazeologia. «Astrel' - AST - Lux» Moskva.

Ш: Šukšin, V., 1974. Besedy pri jasnoj lune. Rasskazy. «Pravda». Moskva.

ШБ: Šukšin, V. 1975. Brat moj. Rasskazy, povesti. «Sovremennik» Moskva.

Шол.: Šolochov, M. 1962. T'ichij Don T. I-IV. «Hud literatura», Moskva

ШP: Šukšin, V. (1984). Rasskazy. «Sovremennik» Moskva. 


\section{For citation:}

Pacsai, I. (2020). The role of Phraseology in the Russian popular writer's works // International ScientificPedagogical Organization of Philologists “WEST-EAST " (ISPOP). Scientific Journal WEST-EAST. Vol 3 N1 (October, 2020). pp. 19-28.

https://doi.org/10.33739/2587-5434-2020-3-19-28

\section{Для цитирования:}

Пачаи, И. (2020). Роль фразеологических единиц в произведениях русских народных писателей // International Scientific-Pedagogical Organization of Philologists “WEST-EAST ” (ISPOP). Scientific Journal WEST-EAST. Vol 3 N1 (October, 2020). C. 19-28.

https://doi.org/10.33739/2587-5434-2020-3-19-28

\section{Information about the author:}

Imre Pacsai - Habilitated Doctor of Philological Sciences Professor, Nyíregyháza High School, Member of the Scientific Council of the International Scientific and Pedagogical Organization of Philologists "WestEast" - ISPOP (Nyíregyháza, Hungary)

e-mail: drpacsai@gmail.com

\section{Сведения об авторе:}

Имре Пачаи - хабилитированный доктор филологических наук, профессор, Ньиредьхазская Высшая школа, член научного совета Международной научно-педагогической организации филологов «Запад-Восток» - ISPOP (Ньиредьхаза, Венгрия)

e-mail: drpacsai@gmail.com

Manuscript received: 11/08/2020

Accepted for publication: $11 / 09 / 2020$

Рукопись получена: 11/08/2020

Принята к печати: 11/09/2020

\section{International Scientific-Pedagogical Organization of Philologists "West-East" ISPOP \\ SCIENTIFIC JOURNAL " WEST-EAST" \\ ISSN (print) - 2587-5434 ISSN (online) - 2587-5523}

